\title{
Respon Pemberian Berbagai Dosis Silika (Si) Cair Dan Interval Pemberian yang Berbeda Terhadap Pertumbuhan Dan Perkembangan Tanaman Bunga Pucuk Merah (Syzigium oleana)
}

\author{
Dahliah Nurdin $^{1}$, Gamaruddin $^{2}$ Muh.Marsuki $^{3}$ \\ ${ }^{1}$ Program Studi Agroteknologi Universitas Al Asyariah Mandar \\ ${ }^{2}$ Program Studi Agribisnis, Universitas Terbuka \\ ${ }^{3}$ Program Studi Agroteknologi Universitas Al Asyariah Mandar \\ Iabdahlia1212@gmail.com \\ '2gamaruddin@ecampus.ut.ac.id
}

\begin{abstract}
Abstrak
Pucuk merah adalah salah satu jenis tanaman hias yang saat ini sedang populer di Indonesia. Warna kemerahan pada daun-daun muda menjadi ciri khas sekaligus daya tarik pada tanaman ini. Maka tak heran jika pucuk merah terkenal sebagai tanaman pagar atau tanaman hias yang mampu mempercantik tampilan sebuah taman. Tanaman ini juga sering digunakan sebagai pembatas jalan baik di daerah perkotaan maupun di perkampungan. Pucuk merah merupakan tanaman hias yang memilik warna daun merah, hijau dan kaya fenol. Permasalahan pada tanaman pucuk merah adalah daun yang berwarna merah tidak sempurna kemerahannya, lambat tumbuh daun pucuk merahnya. Penelitian ini bertujuan untuk mengetahui pengaruh pemberian berbagai dosis Silika Cair dan interval pemeberian yang berbeda terhadap pertumbuhan dan perkembangan tanaman bunga pucuk merah. Penelitian ini dilaksanakan di Kelurahan Darma, Kabupaten Polewali Mandar yang berlangsung dari Juli - Oktober 2017. Penelitian ini menggunakan Rancangan Acak Kelompok dengan pola Faktorial, terdiri dari Faktor pertama adalah pemberian berbagai dosis Unsur Silika terdiri dari tiga taraf yaitu : 0, 2, $4 \mathrm{ml} /$ liter air. Faktor kedua adalah interval pemberian terdiri dari tiga taraf yaitu seminggu sekali, dua minggu sekali dan tiga minggu sekali. Hasil analisis statistik menunjukkan bahwa interaksi antara pemberian Silika Cair dan interval waktu yang berbeda tidak memberikan pengaruh nyata pada semua parameter yang diamati. Pemberian dosis $2 \mathrm{ml} /$ liter air dan pemberian 2 minggu sekali memberikan rata-rata tanaman tertinggi, tercepat pada waktu munculnya daun merah, jumlah daun berwarna merah terbanyak. Sedangkan pemberian $2 \mathrm{ml} /$ liter air dengan pemberian 1 minggu sekali memberikan rata-rata tertinggi pada parameter jumlah daun berwarna hijau dan jumlah cabang keseluruhan
\end{abstract}

Keywords : Pucuk merah, Silika, Interval Pemberian

\section{Pendahuluan}

Pucuk Merah adalah salah satu jenis tanaman hias yang saat ini sedang populer di Indonesia.Warna kemerahan pada daun-daun muda menjadi ciri khas sekaligus daya tarik pada tanaman ini. Maka tak heran jika Pucuk Merah terkenal sebagai tanaman pagar atau tanaman hias yang mampu mempercantik tampilan sebuah taman. Tanaman ini juga sering digunakan sebagai pembatas jalan baik di daerah perkotaan maupun di perkampungan

Tanaman pucuk merah menjadi perhatian karena keberadaan fenol pada daun pucuk merah. Fenol adalah salah satu senyawa turunan benzena yang biasanya berada dalam minyak atsiri. Fenol diketahui merupakan senyawa yang terdapat dalam minyak atsiri daun cengkih dalam bentuk eugenol sebesar 82,13\%, manfaat fenol adalah berperan dalam memberikan aroma yang khas pada produk makanan dan minuman, sebagai zat pewarna bagi makanan dan minuman, dan sebagai antioksidan (Agusta, 2000).

Tanaman pucuk merah akan selalu menghasilkan dua warna karena daun muda yang berwarna merah akan bermunculan sehingga warna tanaman menjadi hijau merah. Indonesia menjadi salah satu negara tempat ideal bagi pucuk merah karena tanaman ini sangat cocok hidup di daerah tropis. Diameter tanaman dapat mencapai 30 $\mathrm{cm}$ dengan tinggi mencapai 7 meter. Usia tanaman dapat mencapai puluhan tahun.

Permasalahan pada tanaman pucuk merah adalah daunnya yang berwarna merah tidak sempurna kemerahannya, lambat tumbuh daun pucuk merahnya diakibatkan karena kebutuhan makanan atau unsur haranya kurang terpenuhi. Salah satu upaya yang bisa dilakukan dalam mangatasi permasalahan tersebut adalah pemberian unsur hara mikro. Salah satunya adalah unsur hara Silika (Si).

Silika pada tanaman berperan dalam mengurangi salinitas dan kekeringan, mengurangi laju transpirasi, meningkatkan penyerapan cahaya, membuat daun menjadi lebih tegak, meningkatkan ketahanan hama dan penyakit, dan membantu memulihkan keseimbangan nutrisi. Silika yang diserap tanaman kedelai akan menyebabkan penebalan dinding sel sehingga dapat menurunkan serangan hama dan patogen penyebab penyakit (Hamayun et al., 2010).

Penelitian ini bertujuan untuk mengetahui pengaruh pemberian berbagai dosis Silika dan interval waktu yang berbeda terhadap pertumbuhan dan perkembangan tanaman bunga pucuk merah. 


\section{Metode Penelitian}

Penelitian ini dilaksanakan di Desa Taan, Kecamatan Tapalang, Kabupaten Mamuju, Sulawesi Barat yang berlangsung pada bulan September sampai November 2015. Metode penelitian ini dilakasanakan dalam bentuk percobaan faktorial yang disusun berdasarkan pola Rancangan AcakKelompok(RAK) yang terdiri dari dua faktor.

Faktor pertama perlakuan dosis bokashi (B) yang terdiri dari tiga taraf yaitu BO : tanpa bokashi tapak kuda, B1: bokashi daun tapak kuda 100gr/tanaman, B2 : bokashi daun tapak kuda200gr/tanaman. Faktor kedua adalah dosis pupuk SP36(S) yang, terdiri dari tiga taraf yaitu 2, 4 dan 6 gram/tanaman. Sehingga dengan terdapat 9 (sembilan) kombinasi perlakuan

\section{Hasil Dan Pembahasan \\ Tinggi Tanaman}

Sidik ragam menunjukkan bahwa dosis pemberian pupuk Silica Cair(B) tidak memberikan pengaruh nyata demikian pula interval waktu pemberian pupuk Silica Cair (W) juga tidak berpengaruh nyata dan interaksi dosis pemberian pupuk Silica Cair dengan interval waktu

Tabel 1.Diagram batang tinggi tanaman pucuk merah

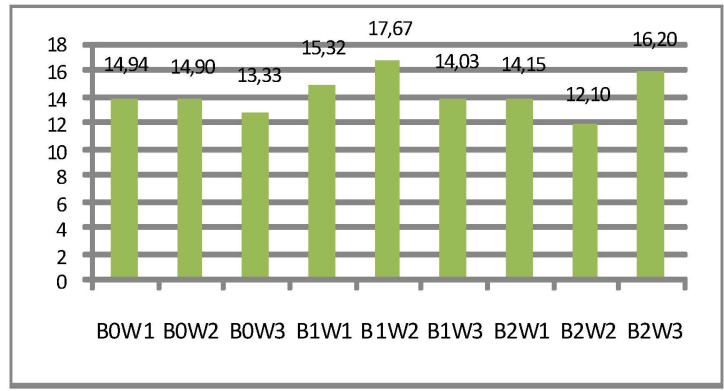

Gambar 1. menunjukkan bahwa dosis pemberian Silika Cair $2 \mathrm{ml} /$ liter air per plot dengan interval waktu pemberian Silika Cair sekali 2 minggu (B1W2), diagram batang tinggi tanamannya lebih tinggi, yaitu $17,67 \mathrm{~cm}$.

Pemberian Silika Cair $2 \mathrm{ml} /$ liter air per plot dengan interval waktu pemberian Silika Cair sekali 2 minggu (B1W2), menghasilkan tinggi tanaman yang lebih baik hal ini terjadi karena tanaman dalam siklus hidupnya tetap melaksanakan pertumbuhan dalam hal ini pertumbuhan tinggi tanaman meskipun dosis yang diberikan pada tanaman pucuk merah dosisnya masih rendah, namun tanaman pucuk merah dalam pertumbuhan tinggi tanamannya tetap mengabsorsi unsur hara mineral dan air dari dalam tanah.

\section{Waktu munculnya daun berwarna merah}

Sidik ragam menunjukkan bahwa dosis pemberian pupuk Silica Cair (B) tidak memberikan pengaruh nyata demikian pula interval waktu pemberian pupuk Silica Cair (W) juga tidak berpengaruh nyata dan interaksi dosis pemberian pupuk Silica Cair dengan interval waktu pemberian yang berbeda (B X W) tidak berpengaruh nyata terhadapwaktu munculnya daun berwarna merah.
Tabel 2. Diagram batang waktu muncunya daun merah

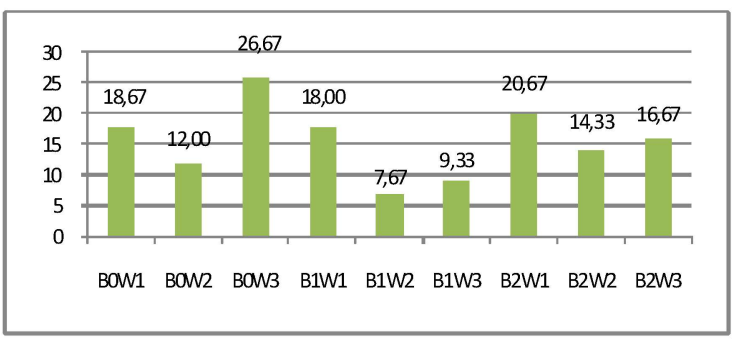

Gambar 2. menunjukkan bahwa dosis pemberian 2 $\mathrm{ml} /$ liter air per plot dengan interval waktu pemberian dua minggu sekali (B1W2), diagram batang waktu muncul daun berwarna merahnya lebih tecepat yaitu sebanyak 7,67 hari.

\section{Jumlah daun yang berwarna hijau}

Sidik ragam menunjukkan bahwa dosis pemberian pupuk Silica Cair (B) tidak memberikan pengaruh nyata demikian pula interval waktu pemberian pupuk Silica Cair (W) juga tidak berpengaruh nyata dan interaksi dosis pemberian pupuk Silica Cair dengan interval waktu pemberian yang berbeda (B X W) tidak berpengaruh nyata terhadap jumlah daun yang berwarna hijau.

Tabel 3. Diagram batang jumlah daun yang berwarna hijau

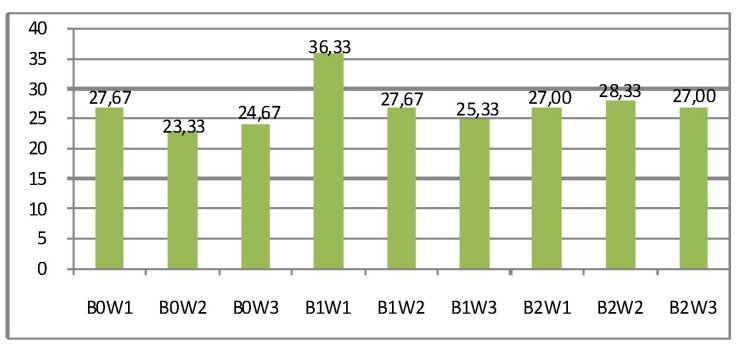

Gambar 3. menunjukkan bahwa dosis pemberian Silika Cair $2 \mathrm{ml} /$ liter air per plot dengan interval waktu pemberian 1 minggu sekali (B1W1), memiliki rata-rata jumlah daun tertinggi yaitu 36,33 helai. Hal ini diduga karena unsur Silika yang diberikan pada tanaman pucuk merah dosisnya sangat sedikit. Silika dibutuhkan tanaman dalam jumlah yang sedikit, yang seharusnya tanaman pucuk merah dalam fase pertumbuhan vegetatif membutuhkan input atau unsur hara yang lebih banyak untuk mendukung proses pertumbuhan dan perkembangannya

\section{Jumlah daun yang berwarna merah}

Sidik ragam menunjukkan bahwa dosis pemberian pupuk biomax(B) tidak memberikan pengaruh nyata demikian pula interval waktu pemberian pupuk biomax (W) juga tidak berpengaruh nyata dan interaksi dosis pemberian pupuk biomax dengan interval waktu pemberian yang berbeda (B X W) tidak berpengaruh nyata terhadap jumlah daun berwarna merah. 
Tabel 4. Diagram batang jumlah daun berwarna merah

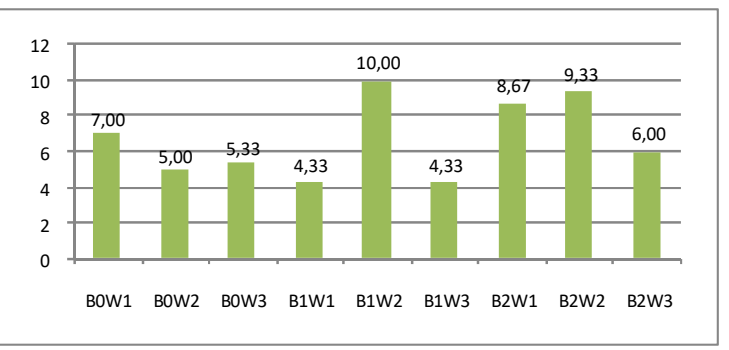

Gambar 4. menunjukkan bahwa dosis pemberian Silika Cair $2 \mathrm{ml} /$ liter air per plot dengan interval waktu pemberian Silika Cair sekali 2 minggu (B1W2), jumlah daun berwarna merahnya lebih banyak, sejumlah 10,00 helai daun. Hal ini diduga karena kandungan dosis dan interval waktu yang diberikan pada tanaman pucuk merah mampu memenuhi kebutuhan unsur hara yang dibutuhkan pucuk merah dalam membentuk jumlah daun yang berwarna merah. Sejalan dengan penelitian Roesmarkam dan Yuwono, 2002 menyatakan bahwa Si dalam daun membantu translokasi karbon hasil fotosintesis dan hasil atau produksi tanaman akan meningkat dengan menguatnya batang dan akar serta lebih efektifnya fotosintesis karena posisi daun (kanopi) menjadi tegak sehingga daun dapat menyerap cahaya matahari lebih banyak.

\section{Jumlah tangkai berwarna merah}

Sidik ragam menunjukkan bahwa dosis pemberian pupuk Silica Cair (B) tidak memberikan pengaruh nyata demikian pula interval waktu pemberian pupuk biomax (W) juga tidak berpengaruh nyata dan interaksi dosis pemberian pupuk biomax dengan interval waktu pemberian yang berbeda (B X W) tidak berpengaruh nyata terhadap jumlah tangkai berwarna merah.

Tabel 5. Diagram batang jumlah tangkai berwarna merah

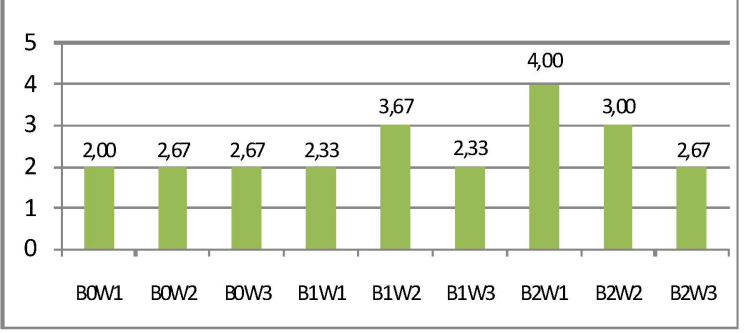

Pemberian Silika Cair $4 \mathrm{ml} /$ liter air per plot dengan interval waktu pemberian Silika Cair sekali seminggu (B2W1), jumlah tangkai berwarna merahnya lebih tinggi, sebanyak 4,00 tangkai. Hasil menunjukkan bahwa pemberian dosis pupuk biomax $4 \mathrm{ml} /$ liter air per plot dengan interval waktu pemberian pupuk biomax sekali seminggu (B2W1), menghasilkan jumlah tangkai berwarna merah yang lebih baik. Tanaman yang diaplikasikan dengan unsur hara silika membantu meningkatkan pertumbuhan tanaman dibandingkan dengan tanaman yang tanpa diaplikasikan silika.

Menurut (Ghanbari et al, 2011), pemberian pupuk silika hanya memiliki sedikit pengaruh pada tahap vegetatif. Fakta penelitian menunjukkan bahwa translokasi hasil asimilat fotosintesis keseluruh tubuh tanaman terjadi pengangkutan namun, masih dalam jumlah yang tidak sesuai dengan kebutuhan hara atau nutrisi yang dibutuhkan oleh tanaman pucuk merah untuk membentuk jumlah tangkai yang berwarna merah atau pada fase generatif tanaman.

\section{Jumlah cabang keseluruhan}

Sidik ragam menunjukkan bahwa dosis pemberian pupuk Silica Cair (B) tidak memberikan pengaruh nyata demikian pula interval waktu pemberian pupuk biomax (W) juga tidak berpengaruh nyata dan interaksi dosis pemberian pupuk Silica Cair dengan interval waktu pemberian yang berbeda (B X W) tidak berpengaruh nyata terhadap jumlah cabang keseluruhan.

Tabel 6. Diagram batang jumlah cabang keseluruhan

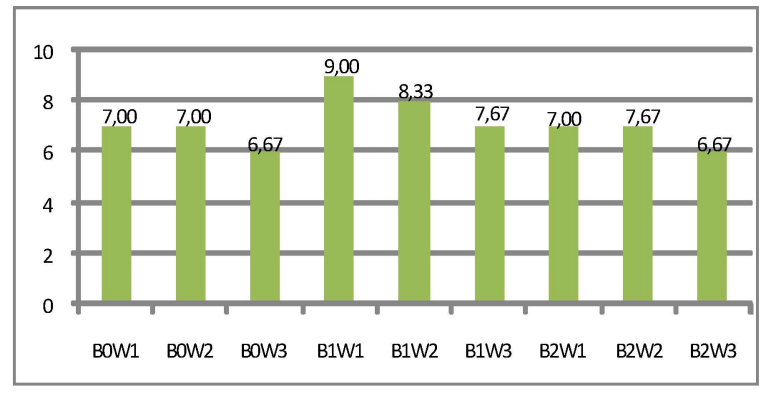

Gambar 6.menunjukkan bahwa dosis pemberian Silika Cair $2 \mathrm{ml} /$ liter air per plot dengan interval waktu pemberian Silika Cair sekali seminggu (B1W1),jumlah cabang keseluruhannya lebih tinggi, yaitu sebanyak 9.00 tangkai.

Hal ini diduga karena Silika Cair mengandung memacu pertumbuhan daun berwarna merah tetapi lebih menghasilkan daun yang berwarna hijau, ini diakibatkan karena silika termasuk unsur hara mikro esensial bagi tanaman sehingga perannya kurang mendapat perhatian, selain dari itu silika dalam fungsinya memper hijau daun tanaman, sejalan dengan penelitian (Ghanbari et al, 2011) pemberian pupuk silika hanya sedikit memiliki pengaruh pada pertumbuhan fase vegetatif tanaman.

Selain itu, pemberian slika dengan seminggu sekali dapat berpengaruh baik pada jumlah cabang, karena unsur hara silika tercukupi didalam tanah. Sejalan dengan penelitian Setyorini dan Abdulrachman (2006), kandungan silika yang cukup pada tanaman padi dapat memperkuat jaringan tanaman, menyebabkan batang dan tangkai tanaman menjadi lebih kuat dan kekar.

\section{Kesimpulan}

Berdasarkan hasil penelitian dan analisis data statistik maka dapat ditarik kesimpulan bahwa:

1. Interaksi antara pemberian berbagai dosis Silika Cair dan interval waktu yang berbeda tidak memberikan pengaruh baik terhadap seluruh parameter pengamatan.

2. Pemberian berbagai dosis Silika Cair tidak memberikan pengaruh baik pada pertumbuhan tanaman bunga pucuk merah. 
3. Interval waktu pemberian Silika Cair tidak memberikan pengaruh baik pada tanaman pucuk merah

\section{Daftar Pustaka}

Agusta, A. 2000.Minyak Atsiri Tumbuhan Tropika Indonesia. Bandung: Penerbit ITB.

Ghanbari A. dan Malidareh. 2011. Silicon application and nitrogen on yield and yield components in rice (Oryza sativa L.) in two irrigation systems. J.Biological. 5:(2).

Hamayun, M., E. Shon, S.A. Khan, Z.K. Shinwari, A.L. Khan, and I. Lee. 2010. Silicon Alleviates The Adverse Effects of Salinity and Drought Stress on Growth and Endogenous Plant Growth Hormone of Soybean (Glycine max L.). Pak. J. Bot. 42(3): 1713-1722.

Roesmarkam, N. W. Yuwono. 2002. Ilmu Kesuburan Tanah. Kanisius. Yogyakarta.
Setyorini, D.dan S. Abdulrachman. 2006. Pengelolaan hara mineral tanaman padi. Balai Besar Penelitian dan Pengembangan Sumber Daya Lahan Pertanian. Hal 109-148.

Takahashi. 2002. Soil, Fertilizer, and Plant Silicon Research in Japan. Elsevier, Amsterdam

Mas'ud, Poerwidodo. 1995. Telaah Kesuburan Tanah. Penerbit Angkasa, Bandung

Makarim, A. K. , E. Suhartatik, dan A. Kartohardjono. 2015. Silikon: Hara Penting pada Sistem Produksi Padi. Iptek Tanaman Pangan. 2(2):195-204.

Nunik, $2013 \quad$ Tentang Pucuk Merah https://biologinunik.wordpress.com di akses pada tanggal 12 desember 2016

Yukamgo, Edo dan Yuwono, N. Widya. 2007. Peran Silikon Sebagai Unsur Bermanfaat pada Tanaman Tebu. Jurnal Ilmu Tanah dan Lingkungan. Universitas Gajah Mada. 7 (2): 103-116 